with the head of $C$. lasiotis of Dr. Sclater in being broader in the parietal regions.

That is to say, Mr. Garrod has found that Sir Stamford Raffles's specimens from Sumatra, on which $R$. sumatrensis is founded, differ from the skull of the animal that the Secretary to the Zoological Society has called R. sumatrensis by the very characters that he himself represents as occurring in the heads of his $R$. sumatrensis and $R$. lasiotis.

Dr. Anderson, in the 'Proceedings of the Zoological Society,' 1872 , p. 129 , describes a female rhinoceros from Chittagong, which he names Rhinoceros sumatrensis, Cuvier, as " ashy grey," and covered with bristles about an inch in length, and long drooping hair on the margin of the ears. The specimen described by Dr. Anderson was purchased by the Zoological Society, and is noticed and figured by the Secretary under the name of Rhinoceros lasiotis (P. Z. S. 1872, p. 493, t. xxiii.). The animal is represented on this plate, I am informed, far darker than it is in nature; and in pp. $791 \& 792$ the ear and crown and side of the head of this animal are figured to show its distinctness from the black rhinoceros, which the Secretary erroneously calls $R$. sumatrensis, overlooking the fact that Mr. Bell, who originally described the Sumatran rhinoceros, especially says the male is "brownish ash," and "the female more of a lead-colour."

The hairy fringe on the ears is common to both species; and I am told that the length of the fringe differs at different periods, and often is not of the same length on the left and right ears.

I think all this proves that the Secretary to the Society has renamed the Sumatran rhinoceros described by Bell, Raffles, and Cuvier, and has applied Cuvier's name to a new species, which I have called, from its very decided difference in colour, Ceratorhinus niger.

XXXIV.-Descriptions of new Species of Fossorial Hymenoptera in the Collection of the British Museum, and of a Species of the rare Genus Iswara belonging to the Family Dorylidæ. By Frederick Smith, Assistant in the Zoological Department of the British Museum.

Family Dorylidæ.

Genus Iswara, Westw.

Iswara fasciata.

Male. Length 6 lines. Black, variegated with yellow and Ann. \& Mag. N. Hist. Ser. 4. Vol. xii. 
white spots and fasciæ, with the legs entirely pale. Head black: antennæ fulvous; the scape in front, the clypeus, and mandibles yellowish white; the tips of the latter ferruginous. Thorax black: the prothorax, a large square spot tridentate at its anterior margin, the tegulæ, scutellum and postscutellum, a large subquadrate macula beneath the wings, and the legs pale yellow; the coxæ and femora at their base above more or less fuscous; wings hyaline, the nervures of the anterior pair black, those of the posterior pair fuscous. Abdomen black: the first segment with a white apical fascia, on the other segments it is basal, broad, occupying two thirds of the segments, and each fascia is narrowed in the middle, being angularly incised at the posterior margin; beneath, the fasciæ on the segments are very deeply incised and become oblong divergent maculæ.

Hab. Sind. This species is in the Indian Museum.

This genus was established by Prof. Westwood in the new series of the Transactions of the Entomological Society of London, vol. i.; a figure of the type, Iswara luteus, is given. This Indian genus is at once separated from the other genera of the family of Thynnidæ by the form of the marginal cell of the anterior wings, it being truncate at the apex, and emitting a short appendicular vein.

\section{Family Pompilidæ.}

\section{Genus Salius, Van der Lind.}

Salius bipunctatus.

Male. Length 4 lines. Black, smooth, shining, and impunctate, with a subovate white spot at the lateral angles of the metathorax. Head ovate; the antennæ inserted on each side of a prominence above the clypeus, the prominence has a central impressed line; a minute white line on the face at the lower orbits of the eyes. Thorax: the posterior margin of the prothorax subangular; wings slightly fuscous, with the apical portion of the anterior pair darkest; the intermediate and posterior tibiæ and tarsi with a few fine short spines. Abdomen as long as the head and thorax united. The entire insect with a fine changeable hoary pile, which is only observable in certain lights.

Hab. Tuscany.

This species agrees with the Salius sexpunctatus of St. Fargeau in having two white spots on the metathorax; but it has no trace of the large white spots, on the second and third segments of the abdomen, which distinguish that insect. St. 
Fargeau does not mention any spots on the face of sexpunctatus: that species is found near Paris; S. bipunctatus may prove to be an extreme variety of it.

\section{Salius dorsalis.}

Female. Length 4 lines. Black, with the pro- and metathorax red. The anterior margin of the clypeus and tips of the mandibles ferruginous. Thorax: the metathorax with the posterior lateral angles produced and spiniform; the wings slightly fuscous, the nervures black; the calcaria at the apex of the tibiæ white; the intermediate and posterior tibiæ and tarsi with a few slight short spines. Abdomen : the base, the apical margins of the first and second segments, and the basal margin of the latter also, with silvery-white pubescence.

Hab. Angara (Siberia).

\section{Genus Chirodamus, Halid.}

Head narrower than the thorax, convex in front; antennæ short, thick, and convolute in the female; labrum exposed. Thorax: narrowed anteriorly from the base of the wings; prothorax short and transverse; the metathorax short, not abruptly truncate, the margins being rounded; wings with one marginal cell, pointed at its apex; three submarginal cells ; the first one third louger than the third, which is narrowed towards the marginal one; the second much narrower than the third, and subquadrate, being a little longer than broad; legs of moderate length, anterior pair raptorial, short, and incrassate; the claws stout, with a large pulvillus between their fork. Otherwise as in the genus Pompilus.

Mr. Haliday has not given any characters whereby to distinguish the insects belonging to this genus; they are, however, indicated by him in his remarks. It will be seen that the characters which separate this genus from that of Planiceps are the narrow head, non-prominent eyes, and the wings having three submarginal cells, and the conspicuous distinction of having the front of the head convex. The abdomen is of the ordinary form of Pompilus, convex, and in no degree compressed. As indicated by Mr. Haliday, the situation of this genus is next to Planiceps.

\section{Chirodamus distinctus.}

Female. Length 6 lines. Black: the head, thorax, and femora with long erect black pubescence, not very dense. The clypeus widely truncate, the truncation slightly incurved; the labrum subangular; the apical portion of the mandibles fer- 
ruginous. The posterior margin of the prothorax angulated; wings slightly fuscous; the knees, tibiæ, and tarsi reddish yellow. Abdomen subsessile, smooth, and shining; the two apical segments with a few long, erect, black hairs.

Hab. Chili (Coquimbo).

In the collection of the British Museum there is a single example of this insect, and three of the typical species $(C$. Kingii, Haliday) - two from the Straits of Magellan, and one from Bahia Blanca, North Patagonia, Argentine Confederation.

\section{Genus Mrgnimia, Shuck.}

This genus was proposed by Shuckard in Lardner's ' Encyclopædia,' published in 1840 ; he gave the name, and pointed out sufficient characters for the discrimination of the species. In 1855 I gave fuller generic distinctions; in consequence, some authors adopt the genus as being mine; others adopt the generic name proposed by Dahlbom, namely Hemipepsis, which appeared in 1845 . The name proposed by Shuckard must take precedence, it having the priority of date.

\section{Mygnimia bellicosa.}

Male. Length 15 lines. Black; the antennæ, clypeus, labrum, palpi, mandibles, tibiæ, and tarsi ferruginous; wings dark fuscous at their base and apex. The clypeus truncate anteriorly; the mandibles black at their apex; the scape of the antennæ black above. The pro- and metathorax with thin short black pubescence; the metathorax truncate, the margin of the truncation elevated, with a transverse shallow striation above, and an abbreviated impressed longitudinal line in the middle at the base; wings black at their base, becoming lighter at the base of the first discoidal cell, from thence it is flavo-hyaline, the apical margins of the wings having a narrow fuscous border; the nervures are pale ferruginous in the subhyaline portion of the wings, and black in the darker part. Abdomen with the base shining, beyond opaque.

Hab. Bengal.

\section{Mygnimia savissima.}

Female. Length 9-12 lines. Black; head, legs, anterior part of the thorax, and two apical segments of the abdomen ferruginous; the ferruginous parts have a fine short bright golden or fulvous pubescence. The mesothorax at the sides and beneath, and the metathorax entirely, black ; the latter is usually more or less tinged with ferruginous above at the base, truncate at the apex, and transversely irregularly striated, the lateral margins sharply elevated; the coxæ and 
trochanters black; wings dark fuscous and with a purple iridescence in certain lights. Abdomen subsessile, obscurely blue, and with a fine obscure purple pile or bloom.

Hab. India (Bombay Presidency).

This species, together with $M$. perplexa of India and $M$. insignis of Africa, belong to a section having the abdomen sessile or subsessile.

\section{Mygnimia lata.}

Female. Length 7-8 $\frac{1}{2}$ lines. Black; head, thorax anteriorly, legs, and abdomen, except its base, reddish yellow; wings dark fuscous, with a purple and violet iridescence. Antennæ pale ferruginous. Thorax : the pro- and mesothorax above reddish yellow, the latter more or less black at its anterior margin; the tegulæ ferruginous; the metathorax truncate, and transversely and irregularly striated; the coxæ and trochanters black, with their apex ferruginous. Abdomen smooth and shining; the basal segment black with a blue tinge.

Hab. Birmah.

\section{Mygnimia intermedia.}

Female. Length 16 lines. Black; the head, pro- and mesothorax, and the legs, except the coxæ, trochanters, and base of the femora, reddish yellow. The antennæ yellow; tips of the mandibles black. The anterior margin of the pro- and mesothorax more or less blackish; the metathorax black, truncate posteriorly, and transversely striated; the wings flavohyaline. Abdomen smooth and shining.

Hab. N. India; Ceylon.

The Sphex flava of Fabricius very closely resembles this species, which occasionally has the apical segment more or less yellow, but its metathorax is always black; the wings have their apical margins only occasionally very narrowly bordered with fuscous: the S. flavus (Pompilus flavus of the 'Systema Piezatorum') has the thorax reddish yellow, except the pectus, which is black; and the species is smaller, varying from ten to twelve lines.'

\section{Mygnimia vitripennis.}

Female. Length 14 lines. Black; the antennæ obscurely ferruginous beneath; the clypeus with scattered fine punctures, and its anterior margin slightly emarginate; the cheeks and the sides of the thorax with short thin black pubescence; the metathorax obliquely rounded, the sides margined, transversely striated, most strongly so at the lateral margins; the wings dark brown, and having a brilliant lustre of coppery 
and purple tints above and also beneath. Abdomen smooth, shining blue-black, and with fine scattered punctures.

The male resembles the female in coloration, the abdomen being of a brighter blue.

Hab. Sumatra.

\section{Mygnimia purpureipennis.}

Female. Length 12 lines. Black; the head, pro- and mesothorax blue, with tints more or less vivid in different lights ; the legs partaking of tints of blue and purple, spinose, the posterior tibiæ with a double row of strong serrations; the metathorax with raised lateral margins, and with irregular transverse carinæ; the wings brilliant purple. Abdomen smooth and shining, and with vivid changeable tints of blue and purple.

The male resembles the female, but has the legs less spinose, and the posterior tibiæ not serrated.

Hab. Java.

\section{Mygnimia momentosa.}

Male. Length $18 \frac{1}{2}$ lines. Black, with brown wings, the two apical segments of the abdomen pale. Head and thorax of a velvet-black, the latter covered above with a short black pile; the clypeus truncate, the labrum rounded, its margin with a small notch in the middle, and narrowly and obscurely ferruginous. The postscutellum compressed and forming a small ferruginous tubercle; wings dark brown, darkest toward their base, their apical margins with a narrow pale border. Abdomen smooth and shining towards the base, and velvet-black on the fourth and fifth segments, the two apical ones of an olive colour, and covered with a short hoary pile.

Hab. Borneo.

This fine species was obtained from the late Dr. Ormerod.

\section{Mygnimia pulchripennis.}

Female. Length 13 lines. Black; the cheeks and thorax with thinly scattered black pubescence, the coxæ also pubescent; the clypeus narrowed anteriorly, where it is truncate and slightly emarginate; the mandibles ferruginous at their apex; the legs spinose, the spines short, thickly set on the tarsi; the posterior tibiæ with a double row of serrations; the metathorax pubescent, and, posteriorly, with a few lateral transverse elevated lines; wings very dark brown, with a vivid tint of green; the apical and posterior margins narrowly purple. Abdomen smooth, slightly shining, and finely, but 
not very closely punctured, having, in certain lights, obscure tints of blue and purple.

Hab. Philippine Islands.

\section{Mygnimia australasice.}

Female. Length 14 lines. Head, thorax, legs, and apical segment of the abdomen ferruginous; the clypeus truncate; the tips of the mandibles, the pectus, and base of the posterior coxæ black; the tibiæ and tarsi with short spines, the posterior tibiæ with a double row of serrations; the mesothorax with a longitudinal black stripe on each side; the wings fulvohyaline, the nervures ferruginous; the metathorax truncate and transversely striated. Abdomen black, with tints of blue.

The male is both coloured and sculptured like the other sex. $H a b$. North-west coast of Australia.

This is the only known species of the genus from Australia.

\section{Family Sphegidæ.}

\section{Genus Ammophila, Kirby.}

\section{Ammophila spinosa.}

Female. Length $12 \frac{1}{2}$ lines. Black; the petiole and legs red; the spines on the tibiæ and tarsi black. Head smooth, the cheeks shining; the face with silvery pile; the clypeus thinly covered with erect black hairs; the scape of the antennæ bright ferruginous. Thorax : transversely striated above; the mesothorax with a central longitudinal channel which runs from the anterior margin to the middle of the disk ; the scutellum longitudinally striated; the central portion of the metath rax rugose, the sides striated; the coxæ and trochanters black, the legs bright red; two or three of the apical joints of the tarsi fuscous or black; the wings subhyaline, the nervures ferruginous. The abdomen blue-black; the apical segments with a changeable cinereous pilosity.

Hab. Hong Kong.

\section{Ammophila laviceps.}

Female. Length 9 lines. Black; with the legs and abdomen, except the two apical segments, ferruginous. Head smooth, slightly shining, and with distant fine shallow punctures ; the clypeus and face anteriorly with stronger and larger punctures, the former with a central depression. Thorax : a central impressed line in the middle of the prothorax, which extends to the disk of the mesothorax, the latter punctured; the scutellum and postscutellum longitudinally strongly stri- 
ated; the enclosed space on the metathorax above transversely striated, coarsely so in the middle, and finely so at the sides; beyond the space it is rugose; the wings subhyaline, the nervures black; the coxæ and trochanters black. Abdomen: the base of the second joint of the petiole black.

Hab. Santiago.

\section{Ammophila barbata.}

Female. Length 13-13 $\frac{1}{2}$ lines. Black; the wings hyaline, their apical margins fuscous beyond the apex of the marginal cell, the fuscous border sharply defined. Head: the face and cheeks with silvery pile, and covered thinly with long black hairs. Thorax : very thinly covered with hoary pubescence; a silvery spot at the posterior margin of the prothorax; the tubercles, two oblique stripes at the sides of the thorax, and the apex of the metathorax silvery; the coxæ, trochanters, and femora beneath covered with changeable silvery pile; the prothorax coarsely transversely striated ; the mesothorax with a central longitudinal impressed line, and transversely and coarsely striated, the striæ punctured; an elongate small space before the scutellum punctured and without striæ; the scutellum longitudinally punctate-striate; an elongate angular space at the base of the metathorax rugose, on each side of which is an oblique striation. Abdomen black, with a blue tinge, the petiole two-jointed.

Hab. Mexico.

This species closely resembles A. gryphus of N. America, California, and Texas ; but the prothorax is shorter, the sculpture of the thorax coarser, and the insect much more pubescent.

[To be continued.]

\section{BIBLIOGRAPHICAL NOTICES.}

Researches in Zoology. Illustrative of the Structure, Habits, and Economy of Animals. By John Blackwall, F.L.S. London: Van Voorst, 1873.

Tнат frequent inquiries should have been made for this book, originally published in 1834, is, we think, sufficient proof, if any were wanting, of its value, and fully justifies Mr. Blackwall in issuing a second edition, "comprising," as he says, "such additions and emendations as subsequent investigations have enabled me to effect." For ourselves we have read through this work attentively, and have been struck with the amount of careful observation it contains, and still more with the wise caution exercised wherever any attempt is made by the author to form conclusions from the facts observed. Take 


\section{$2 \mathrm{BHL}$ Biodiversity Heritage Library}

Smith, Frederick. 1873. "XXXIV.-Descriptions of new species of fossorial hymenoptera in the collection of the British Museum, and of a species of the rare genus Iswara belonging to the family Dorylidæ." The Annals and magazine of natural history; zoology, botany, and geology 12, 253-260. https://doi.org/10.1080/00222937308680752.

View This Item Online: https://www.biodiversitylibrary.org/item/63347

DOI: https://doi.org/10.1080/00222937308680752

Permalink: https://www.biodiversitylibrary.org/partpdf/58953

\section{Holding Institution}

University of Toronto - Gerstein Science Information Centre

\section{Sponsored by}

University of Toronto

\section{Copyright \& Reuse}

Copyright Status: NOT_IN_COPYRIGHT

This document was created from content at the Biodiversity Heritage Library, the world's largest open access digital library for biodiversity literature and archives. Visit BHL at https://www.biodiversitylibrary.org. 